\title{
PENGKEMASAN KULINER LOKAL DAN CINDERAMATA LOKAL DALAM MENDUKUNG PENGEMBANGAN DESA WISATA TISTA, KECAMATAN KERAMBITAN, KABUPATEN TABANAN
}

\author{
Agus Muriawan Putra ${ }^{1}$, Ni Nyoman Sri Aryanti², IB. Ketut Astina ${ }^{3}$, dan IB. Dwi Setiawan ${ }^{4}$
}

\begin{abstract}
Tista village has a very diverse potential to be developed into a tourist attraction, namely the potential of nature, cultural potential, culinary potential, spiritual potential, and of course the potential of Human Resources. These potentials are the capital of Tista Village to be a tourist village, where Tista Village is designated as a tourist village by the Regent of Tabanan Number: 180/319/03 / HK \& HAM / 2016, 26th October 2016. Tista villagers strongly support the village to be a rural tourism, this can be proven by the enthusiasm of the community held Tista Festival held on 6-8 January 2017, where in the festival was introduced various tourism potentials owned Tista Village and socialize the Village Tista Stipulation as a rural tourism, so the whole Tista village community and the surrounding villages know that Tista Village is officially a rural tourism. For the community there must be a change of attitude in maintaining the status of the rural tourism, such as preserving the village environment, maintaining cleanliness, maintaining cultural and spiritual sustainability, growing creativity and innovation to cultivate and manage resources owned, and the most important is to increase knowledge and understanding related to tourism (hospitality). The tourist attraction of rural tourism certainly requires some concept of development and management that will be able to withstand longer tourist visits staying in Tista Rural Tourism. To provide a more diverse alternative tourism again, it is necessary to plan a package/local tourism products that can be packaged by the village community Tista a choice of attraction to tourists who visit. These local potentials that are part of life and daily activities of Tista Village community need to be introduced to tourists so that tourism development in Tista Rural Tourism can show something different, where potency which have chance to be developed is local culinary potency, where in Tista Village can be found in various local culinary communities that are very diverse from various preparations and flavors. In addition, to maintain a positive image of tourism in Tista Rural Tourism required something that is remembered and a characteristic that is obtained from the village Tista. Something that is a local souvenir, so that the Tista community need to be creative, both individually and in groups to prepare and produce local souvenirs whose nuance is the uniqueness and local wisdom of Tista. Because in tourism, what we "sell" is service accompanied by souvenir/hand brought by tourists to the area of origin and also as a promotional event to lure other tourists to come even more to the Tista Rural Tourism. For that reason, the Team of Community Service of the Faculty of Tourism, Udayana University implementing service in the Tista Rural Tourism with the topic "Packaging Local Culinary and Local Souvenirs in Support Tista Rural Tourism Development, Kerambitan District, Tabanan Regency".
\end{abstract}

Keywords: Local Culinary, Local Souvenir, Rural Tourism, Community Participation

\footnotetext{
${ }^{1}$ Program Studi D-IV Pariwisata Fakultas Pariwisata, Universita Udayana, agus_muriawan@yahoo.com

${ }^{2}$ Program Studi D-IV Pariwisata Fakultas Pariwisata, Universita Udayana, sriaryanti@yahoo.com

${ }^{3}$ Program Studi D-IV Pariwisata Fakultas Pariwisata, Universita Udayana, ida.bgsastina@yahoo.com

${ }^{4}$ Program Studi D-IV Pariwisata Fakultas Pariwisata, Universita Udayana, setiawangos@gmail.com
} 


\section{PENDAHULUAN}

\subsection{Analisis Situasi}

Kepariwisataan merupakan salah satu industri yang berkembang pesat di Indonesia dan terbukti menyumbangkan pendapatan yang besar. Kepariwisataan akan terus berkembang selaras dengan perkembangan industrialisasi dan perubahan gaya hidup yang menyebabkan orang-orang semakin memiliki kemampuan untuk berwisata dan memiliki waktu yang lebih banyak untuk melakukan perjalanan, khususnya ke Indonesia.

Melihat prospek kepariwisataan inilah, pemerintah Indonesia berusaha mengembangkan kepariwisataan secara lebih intensif, yakni dengan mempersiapkan dan memperbaiki kualitas objek dan atraksi yang ada dengan tetap menggali potensi wisata yang dimiliki, melakukan perencanaan, dan pengelolaan pembangunan kepariwisataan yang lebih baik. Dengan demikian, diharapkan Indonesia mampu merebut pasar wisatawan dan bersaing dengan berbagai destinasi wisata yang ada di dunia. Keseriusan pemerintah dalam mengelola sektor pariwisata dapat dilihat dari berkembangnya daya tarik wisata di Bali dan berbagai upaya telah dilaksanakan pemerintah seperti melakukan program pengembangan wisata melalui instansi terkait, kerjasama dengan investor serta penggalangan bentuk keterlibatan masyarakat lokal (community based tourism).

Kabupaten Tabanan merupakan salah satu kabupaten di Bali yang memiliki daya tarik wisata bagi wisatawan yang datang mengunjunginya. Pengembangan pariwisata Kabupaten Tabanan diarahkan pada pengembangan produk wisata alam dan budaya, pemasaran daya tarik wisata, pembinaan dan pengembangan nilai-nilai budaya, pembinaan kesenian, peninggalan sejarah yang bertujuan untuk mengembangkan daya tarik wisata potensial sebagai daya tarik utama bagi wisatawan, yang menjadikan pariwisata sebagai sarana peningkatan pendapatan masyarakat, dan daerah, serta media bagi penciptaan lapangan dan kesempatan kerja.

Salah satu daya tarik yang berpotensi untuk dikembangkan adalah Desa Tista, Kecamatan Kerambitan, Kabupaten Tabanan. Desa Tista merupakan salah satu desa yang terletak di Kecamatan Kerambitan, Kabupaten Tabanan ini merupakan salah satu desa wisata yang sedang berkembang, di mana Desa Tista memiliki keunikan dan daya tarik tersendiri yakni budaya langka, yaitu: "Andir" serta memiliki daerah yang masih kental alam pedesaannya dan masih kental dengan tradisionalitasnya, sehingga sangat cocok sebagai desa wisata.

Penduduk Desa Tista sebagian besar memeluk Agama Hindu dengan adat gotong- royong yang mengakar kuat. Masyarakat Desa Tista cukup aktif dalam kegiatan kesenian dengan memanfaatkan "Balai Banjar" untuk melaksanakan kegiatan tersebut dan ditambah dengan terbentuknya Kelompok Sadar Wisata (Pokdarwis), diharapakan masyarakat lebih mendukung pengembangan kepariwisataan. Melihat potensi yang dimiliki oleh Desa Wisata Tista yang sangat besar, maka untuk mendukung pengembangannya, masyarakat secara bertahap diberikan pemahaman dan pelatihan tentang potensi lokal yang dimiliki yang dapat dikemas menjadi produk wisata lokal yang dapat disajikan kepada wisatawan dalam pengembangan desa wisata tersebut, di mana di dalam Pengabdian Kepada Masyarakat ini yang difokuskan adalah "Pengkemasan Kuliner Lokal dan Cinderamata Lokal yang dapat melibatkan masyarakat Desa Tista secara langsung.

\subsection{Tujuan Kegiatan}

Tujuan dari kegiatan pengabdian kepada masyarakat ini adalah untuk memberikan pemahaman yang positif kepada masyarakat Desa Tista untuk berperan aktif dan berpartisipasi aktif serta berkreasi 
inovatif dalam menggali potensi lokal Desa Tista, khususnya berkaitan dengan potensi kuliner lokal dan cinderamata lokal yang dimiliki Desa Tista dalam mendukung pengembangan dan pengelolaan Desa Wisata Tista, sehingga dapat memberikan manfaat ekonomi secara langsung kepada masyarakat Desa Tista melalui pembuatan produk/paket kuliner dan cinderamata yang dapat dijual kepada wisatawan yang berkunjung atau dijual ke desa-desa sekitarnya atau dapat dipasarkan ke swalayanswalayan di Kabupaten Tabanan, di mana hal ini akan melahirkan home-home industry yang dikelola dan dikerjakan langsung oleh masyarakat lokal.

\section{METODE PEMECAHAN MASALAH}

Adapun kegiatan pemecahan masalah dalam pengabdian kepada masyarakat ini, yaitu:

1. Memberikan penyuluhan dan pelatihan langsung kepada masyarakat Desa Tista tentang pengolahan kuliner lokal dan pembuatan cinderamata lokal sebagai sebuah produk wisata.

2. Memberikan pelatihan tentang pelayanan kepariwisataan dan hospitality.

2. Mengadakan inventarisasi potensi wisata bersama masyarakat Desa Tista untuk dapat dibuatkan sebuah program pengembangan dan pelatihan secara berkelanjutan kepada masyarakat.

3. Mengaktifkan home industri di Desa Tista untuk menciptakan berbagai produk wisata lokal Desa Tista, seperti cinderamata lokal, membuat makanan-makanan ringan yang bercirikan alam Tista, sehingga dapat menambah penghasilan masyarakat.

4. Mengusulkan pendirian Koperasi Desa untuk menampung hasil produksi dari masyarakat, sehingga ada wadah dalam hal pemasaran produk tersebut, seperti produk kuliner dan cinderamata.

5. Membentuk pengelola produk lokal sebagai manajemen produk untuk dapat mengatur dan memfasilitasi kegiatan atau aktivitas dari masyarakat Desa Tista untuk berproduksi, sehingga tidak terjadi persaingan yang tidak sehat serta masyarakat dapat melakukan kegiatan produksi secara berkelanjutan.

6. Bekerjasama dengan pihak terkait dalam hal pemasaran produk.

7. Menjadikan Desa Tista sebagai Desa Binaan dari Fakultas Pariwisata Universitas Udayana, sehingga secara berkelanjutan dapat dibina dan didampingi berkaitan dengan kepariwisataan dan sebagai poin dalam Akreditasi Fakultas.

Metode yang digunakan dalam melakukan Pengabdian Kepada Khalayak Sasaran adalah:

Metode pengumpulan data melalui observasi dan survei lapangan serta program pemberdayaan melalui penyuluhan, pelatihan, dan pendampingan, yaitu: pertemuan secara berkala antara Tim Pengabdian Kepada Masyarakat dengan Khalayak Sasaran. Model pendekatan yang dilakukan meliputi: (1) Model Partisipatory Rural Appraisal (PRA); (2) Model Entrepreneurship Capacity Building (ECB); dan (3) Model Teknologi Transfer (TT).

\section{HASIL DAN PEMBAHASAN}

\subsection{Pembuatan Kuliner Lokal}

Berbagai kuliner lokal terdapat di Desa Tista, di mana berbagai kuliner tersebut merupakan asli Desa Tista karena bahan-bahan yang digunakan didapatkan langsung dari Desa Tista. Masyarakat mengolah dan memproduksi kuliner lokal tersebut secara manual dan hanya untuk dipergunakan sehari-hari saja, sehingga dengan Kegiatan Udayana Mengabdi ini masyarakat dilatih untuk mengkemas berbagai kuliner lokal tersebut, sehingga mempunyai nilai ekonomis yang lebih tinggi dan dapat digunakan sebagai cinderamata lokal Desa Tista. Adapun beberapa kuliner lokal Desa Tista, yaitu: 


\subsubsection{Jajan Kaliadrem}

Jajanan tradisional yang terbuat dari tepung beras ini memang enak dijadikan sebagai teman minum teh atau kopi di sore hari. Bentuknya bisa bulat seperti donat mini atau berbentuk segitiga dengan lubang bulat di bagian tengahnya yang terkadang jumlah lubangnya bisa berjumlah satu sampai tiga buah. Teksturnya yang sedikit liat terasa gurih manis di dalam mulut. Penyuka jajanan tradisional pastinya akan menyukai kue yang satu ini. Kue khas Desa Tista ini banyak dijumpai di pasar-pasar tradisional yang ada di Desa Tista, kita pun tak sulit untuk menemukan jajanan khas ini. Kue ini selain bisa dinikmati sebagai camilan sehari-hari, kue ini juga banyak diserbu saat ada Upacara-Upacara Adat di Bali atau saat Perayaan Hari Raya Besar Keagamaan, seperti: Galungan dan Kuningan. Apabila ingin membuatnya di rumah, bahan-bahan untuk membuatnya pun tidak begitu sulit untuk ditemukan karena hanya memerlukan bahan-bahan yang cukup sederhana, seperti: tepung beras, gula merah, kelapa, wijen, garam, air, minyak kelapa, dan vanili secukupnya.

\subsubsection{Apem Kukus Ubi Ungu Khas Desa Tista}

Kue apem adalah salah satu jenis kue jajanan pasar yang termasuk ke dalam golongan kue tradisional asli indonesia. Kue ini memiliki cita rasa manis yang pas dan juga banyak digemari oleh semua kalangan. Adanya campuran ubi ungu dalam kue ini membuatnya semakin menarik dengan corak warnanya yang sedap dipandang mata. Kue apem ini pun juga tidak mengandung bahan pengawet, karena menggunakan bahan-bahan tradisional. Kue apem ungu ini terbuat dari campuran tepung beras, tepung ketan, atau ragi instan, gula, ubi ungu, dan juga berbagai bahan pelengkap lainnya. Kue ini biasanya dibuat dengan cara dikukus dengan langseng yang sudah berisi dengan air panas atau air mendidih, proses pembuatan kue basah ini memang memerlukan waktu yang cukup lama, karena setelah pembuatan adonan kue ini tidak langsung dikukus tetapi dibiarkan sampai mengembang. Setelah itu baru adonan akan siap untuk dikukus.

\subsubsection{Loloh Cemcem}

Loloh cemcem merupakan salah satu kuliner lokal terkenal di Bali, salah satunya yang berada di Desa Tista. Cemcem itu sendiri merupakan salah satu daun-daunan yang memiliki banyak khasiat yang berguna bagi tubuh. Biasanya daun cemcem banyak dikonsumsi dengan cara dihaluskan untuk mendapatkan sari hijau daun tersebut, setelah itu dicampurkan dengan air kelapa muda beserta daging kelapanya dan terakhir dengan campuran bahan lainnya, seperti: garam, jeruk nipis, dan bisa ditambah es. Setelah semua bahan-bahan tercampur, minuman yang dikenal dengan nama Loloh Cemcem ini siap dinikmati.

\subsubsection{Rujak Tibah}

Rujak tibah merupakan suatu minuman lokal yang terbuat dari sari buah mengkudu yang dicampur dengan bahan-bahan tradisional. Buah mengkudu sangat gampang ditemui karena berbagai macam manfaat yang terkandung di dalamnya. Cara pembuatan Rujak Tibah ini pun bisa dikatakan cukup mudah dan dengan bahan-bahan yang mudah ditemui. Adapun bahan campuran tradisionalnya, yaitu, gula aren, garam, dan jeruk nipis. Minuman ini juga memiliki banyak manfaat bagi kesehatan, seperti: penyakit diabetes, demam, dan sebagainya. Minuman lokal ini juga banyak dijumpai di desa-desa, salah satunya adalah Desa Tista yang juga tetap melestarikan minuman tradisional ini.

\subsubsection{Nasi Bejek}

Desa Tista memiliki kuliner lokal yang unik dan jarang ditemui di desa lainnya, yaitu: Nasi Bejek. Nasi Bejek adalah nasi yang dicampur dengan bumbu khas Bali untuk melengkapi rasa dari nasi itu sendiri kemudian dibejek dengan tangan dan diisi dengan lauk, seperti: tempe, tahu, telur, dan sambal. 


\subsubsection{Bakso Lele}

Lele sudah lama dibudidayakan oleh masyarakat Desa Tista. Selain dikonsumsi secara langsung, masyarakat juga memanfaatkannya dengan mengolahnya menjadi bahan konsumsi yang bernilai jual, seperti: bakso lele dan nugget lele. Seperti namanya, bahan dasar bakso lele berasal dari ikan lele dan dicampur dengan bahan lainnya, seperti: tepung tapioka, bawang putih, garam, dan air secukupnya. Bakso lele ini dikemas dalam bentuk setengah matang, di mana untuk dapat siap dihidangkan harus digoreng atau direbus terlebih dahulu. Hingga sekarang bakso lele diproduksi untuk masyarakat Desa Tista saja, yang dilakukan oleh Ibu-Ibu PKK Desa Tista.

\subsubsection{Nugget Lele}

Produk olahan ikan lele lainnya adalah nugget lele. Nugget ini diproduksi bersamaan dengan bakso lele dan dilakukan oleh Ibu-Ibu PKK Desa Tista. Sama halnya dengan bakso lele, nugget ini diproduksi untuk kebutuhan konsumsi Desa Tista saja dan belum dipasarkan di luar desa. Bahan dasar nugget ini dicampur dengan tepung tapioka, tepung maizena, wortel, garam, merica, dan bumbu lokal lainnya. Sama hal-nya dengan bakso lele, nugget lele dikemas lebih hygienis dan lebih menarik untuk dapat dijadikan cinderamata lokal khas Desa Tista.

\subsubsection{Donat Ubi Ungu}

Selain padi, hasil pertanian Desa Tista yang masih unggul hingga saat ini adalah ubi ungu. Banyaknya produksi tanaman ini membut masyarakat mengolahnya menjadi donat ubi ungu. Donat ini sama dengan donat pada umumnya hanya bahan dasarnya saja yang berbeda yakni ubi ungu. Warna donat ini sangat khas, karena warna di luar permukaannya sama dengan donat pada umumnya yakni coklat, namun di dalamnya berwarna ungu. Teksturnya lebuh lembut, tanpa pengawet dan kandungan zat besi dalam donat menjadikan Donat Tista ini sangat khas.

\subsubsection{Loloh Sereh}

Loloh sereh merupakan salah satu potensi minuman lokal yang terdapat di Desa Tista. Masyarakat memanfaatkan tanaman-tanaman yang memiliki khasiat, seperti: sereh dan jahe untuk dijadikan minuman loloh sereh yang berkhasiat untuk kesehatan. Saat ini loloh sereh belum diproduksi dalam jumlah yang banyak hanya sering disungguhkan untuk menjamu tamu di keluarga. Selain disuguhkan untuk tamu, minuman ini biasa dikonsumsi pada malam hari untuk menghangatkan tubuh.

Selain kuliner lokal yang sudah ada dan mempunyai ciri khas serta berbahan lokal Desa Tista dan masih melibatkan Ibu-Ibu PKK Desa Tista, maka dalam Kegiatan Udayana Mengabdi yang dilaksanakan oleh Tim Udayana Mengabdi Program Studi Diploma IV Pariwisata, Fakultas Pariwisata, Universitas Udayana digali lagi jenis kuliner lokal lain sebagai variasi dari jenis kuliner yang sudah ada dan berbahan lokal Desa Tista yang mudah didapatkan oleh masyarakat melalui program pelatihan yang melibatkan langsung Ibu-Ibu PKK Desa Tista untuk secara langsung ikut terlibat dalam pembuatan beberapa jenis kuliner lokal. Di mana dalam pembuatan kuliner lokal ini, dipandu oleh seorang Chef, dengan memberikan resep yang dapat dipraktekkan oleh Ibu-Ibu PKK Desa Tista secara langsung di rumah masing-masing dan dapat dilakukan pengimbasan kepada masyarakat yang lain.

Adapun beberapa jenis kuliner lokal yang dihasilkan adalah sebagai berikut:

1. Bakpao Ubi Ungu

Cara Membuat Bakpao: 
1. Untuk membuat sajian kali ini dapat dilakukan dengan menyiapkan sebuah wadah dekat dengan jangkauan anda. Selanjutnya, silahkan masukkkan ubi ungu bersama dengan vanila bubuk, tepung terigu, gula halus, fermipan, susu bubuk dan juga garam halus. Aduk-aduk semua bahan ini secara merata sampai tercampur dan teraduk.

2. Selanjutnya adalah dengan menambahkan sedikt air kedalamnya dengan perlahan sambil diuleni secara merata dengan menggunakan tangan.

3. Lalu tambahkan dengan menggunakan pewarna ungu dan aduk-aduk kembali sampai semua bahan ini tercampur dan teraduk secara merata dan warna dari adonan berubah menjadi ungu merata.

4. Selanjutnya adalah dengan menambahkan mentega dan uleni bahan ini secara merata sampai kalis dan tercampur. Diamkan adonan selama kurang lebih 30 menit dengan ditutupi menggunakan kain bersih.

5. Kempeskan adonan bakpao dan bagi adonan menjadi beberapa bagian. Setelah itu, pipihkan kembali adonan dan bentuk kembali dengan bentuk bulat secara merata. Lalu diamkan kembali selama kurang lebih 30 menit agar mengembang secara merata.

6. Siapkan kukusan dan kukus bakpao didalamnya sampai matang dan empuk secara merata.

7. Bila sudah matang, angkat sajian ini dari kukusan dan hidangkan dalam piring saji untuk kemudian anda akan siap menikmati sajian ini.

2. Sirup Ubi Ungu

Cara Membuat Sirup Ubi Ungu:

1. Ubi ungu direbus dengan air sampai air berkurang $1 / 4$ nya ( \pm 20 menit api sedang), saring dan rebus kembali air ubi ungu.

2. Lalu tambahkan 500 gula pasir, rebus aduk-aduk sampai larut.

3. Masukkan cairan asam jawa, aduk rata dan dinginkan, siap dikemas dan disajikan.

3. Bolu Pisang

Cara Membuat Bolu Pisang:

1. Terlebih dahulu pisang di haluskan hingga benar-benar halus dan lembut, untuk menghaluskan pisang bisa menggunakan sendok dengan cara di tekan-tekan atau juga bisa menggunakan blender.

2. Untuk memudahkan adonan tercampur, mentega dicairkan dengan cara dipanaskan lalu mentega setelah cair campurkan ke dalam adonan yang lainnya.

3. Sediakan sebuah wadah yang besar untuk membuat adonan, masukkan telur sambil di kocok hingga lembut dan mengembang, lalu tambahkan gula pasir, coklat bubuk, garam, tepung terigu, aduk lagi hingga benar-benar tercampur dan rata.

4. Tambahkan vanilla bubuk, baking powder, dan aduk sampai rata kembali. Setelah adonan semuanya rata, lalu pisang yang telah dilembutkan masukkan ke dalam adonan dan campurkan hingga rata. Sediakan Loyang lalu olesi dengan mentega agar adonan tidak lengket.

5. Masukkan adonan kedalam Loyang, kemudian adonan di kukus dengan menggunakan api yang kecil saja hingga adonan matang.

6. Untuk mencoba atau mengecek kue matang atau belum, bisa menggunakan lidi atau garpu.

7. Angkat dan siap disajikan

4. Selai Nangka

Cara Membuat Selai Nangka:

1. Masukkan seluruh bahan pada blender, haluskan.

2. Tuangkan pada panci, masak diatas api yang berukuran kecil sambil diaduk sampai mongering serta kalis.

3. Angkat dan dinginkan, taruh pada wadah kedap udara. 
5. Sirup Mengkudu Rempah

Cara Membuat Sirup Mengkudu Rempah:

1. Pilih mengkudu tua yang dagingnya masih berwarna putih segar. Potong menjadi 4 bagian, lalu rendam selama $1 / 2$ jam (30 menit).

2. Ambil kunyit putih, cuci bersih dan kupas kulitnya kemudian masukkan ke dalam panci bersama 2 liter air.

3. Masukkan potongan mengkudu yang sudah direndam sebelumnya, rebus sampai airnya tersisa satu liter.

4. Masukkan kayu manis dan cengkeh, aduk-aduk dan rebus beberapa saat dengan api kecil.

5. Sebelum diangkat tambahkan gula atau madu sesuai selera, aduk sampai larut dan rata.

6. Angkat, lalu saring air rebusan tadi menggunakan kain lembut (kain muslin tipis atau kasa).

7. Diamkan beberapa saat hingga air menjadi jernih. Dinginkan lalu dikemas dan siap disajikan.

6. Permen Gula Asem

Cara Membuat Permen Gula Asem:

1. Larutkan asem dan air, saring

2. Rebus air bersama gula dan jahe. Lalu tuangkan larutan asam tadi, aduk rata. Biarkan sampai mendidih.

3. Masukkan tepung roti sambil sesekali diaduk sampai kalis. Angkat dan dinginkan, kemudian permen dibentuk kotak-kotak atau bulat-bulat kecil menurut selera.

4. Gulingkan permen asem ke dalam gula pasir hingga tertutup rata.

5. Simpan permen asem dalam toples atau wadah yang tertutup rapat.

6. Manisan permen gula asem siap disajikan.

7. Kue Kering Kelapa Renyah

Cara Membuat Kue Kering Kelapa Renyah:

1. Sangrai kelapa parut diatas api kecil saja sampai kering namun jangan sampai berwarna kuning apalagi gosong.

2. Panaskan oven dengan api kecil suhu $150^{\circ} \mathrm{C}$

3. Ambil 5 sendok makan kelapa sangrai untuk taburan diatasnya.

4. Kocok kuning telur, mentega, garam, vanili bubuk, kelapa parut, gula halus dan tepung terigu dengan menggunakan mixer hingga tercampur rata.

5. Uleni adonan dengan tangan sebentar hingga adonan dapat dibentuk.

6. Ambil adonan secukupnya kemudian bentuk bulat pipih yang sudah dioles dengan meentega.

7. Taburi dengan kelapa parut pada bagian atasnya.

8. Panggang dalam oven selama \pm 20 menit (warna agak kecoklatan) lalu diamkan sampai dingin.

9. Masukkan kue ke dalam toples dan siap untuk disajikan.

\subsection{Pembuatan Cinderamata Lokal}

Hal yang penting untuk diadakan dalam kegiatan kepariwisataan adalah cinderamata. Karena cinderamata merupakan sesuatu yang menjadi pengingat ataupun menjadi bukti bahwa wisatawan bersangkutan pernah datang atau berkunjung ke suatu tempat. Dalam hal ini yang terpenting adalah cinderamata yang sesuai dengan karakteristik dan kearifan lokal dari suatu daerah tujuan wisata atau yang sering disebut dengan cinderamata lokal.

Desa Tista sebagai Desa Wisata juga memiliki berbagai cinderamata lokal yang dapat diberikan kepada wisatawan yang berkunjung ke Desa Tista. Adapun beberapa cinderamata lokal yang disiapkan di Desa Tista, yaitu: 


\subsubsection{Berbagai Kerajinan Dari Sampah}

Di Desa Tista terdapat Bank Sampah, di mana masyarakat Desa Tista dapat membawa berbagai sampah, baik sampah organik maupun sampah non organik untuk dihargakan dengan uang. Kemudian sampah tersebut dipilah berdasarkan jenisnya, yaitu yang organik dan yang non organik. Sampahsampah organik akan diolah dijadikan kompos dan dipergunakan untuk keperluan pertanian di Desa Tista dan juga dapat dimanfaatkan oleh orang luar yang berminat menggunakan bahan kompos dari Desa Tista. Sampah-sampah non organik, seperti: bekas-bekas botol minuman, koran-koran bekas akan diolah menjadi barang-barang kerajinan yang sangat menarik dan mempunyai nilai jual yang tinggi. Kerajinan yang dapat dibuat oleh masyarakat Desa Tista dari sampah non organik tersebut adalah tas dengan berbagai bentuk dan bokoran dalam berbagai bentuk. Barang-barang tersebut dijadikan cinderamata untuk wisatawan dan juga dapat dijual sampai ke luar Desa Tista. Masyarakat Desa Tista sangat antusias untuk mengembangkan kerajinan ini dan dibantu oleh Tim Udayana Mengabdi, sehingga di samping dapat menambah penghasilan masyarakat juga secara tidak langsung dapat menjaga kebersihan Desa Tista dan dapat mengembangkan budaya hidup bersih, sehingga Program Sapta Pesona dapat tercapai dan sukses.

\subsubsection{Gelang Dan Kalung Dari Biji Buah Asem}

Buah Asem kalau di Bali disebut dengan "Buah Celagi", di mana Pohon Celagi merupakan pohon yang mempunyai nilai magis di Bali. Di Desa Tista ada sebuah pura yang disebut dengan Pura Celagi. Pura Celagi merupakan salah satu pura yang berumur sangat tua, di mana pura tersebut sesuai dengan namanya Pura Celagi, yaitu ditumbuhi Pohon Celagi yang sangat besar yang sangat dihormati oleh masyarakat Desa Tista. Dengan adanya Pura Celagi tersebut menambah suasana sakral dan diyakini oleh masyarakat bahwa Pohon Celagi yang ada di Desa Tista bisa dipakai sebagai obat dan keperluan Upacara Agama, sehingga perlu untuk dipelihara dan dilestarikan, dengan demikian secara tidak langsung tumbuh-tumbuhan di Desa Tista dapat terjaga dengan baik. Biji Celagi tersebut dapat dijadikan kalung dan gelang untuk cinderamata lokal Desa Tista karena permukaan Biji Celagi yang licin dan mengkilat, sehingga ketika dijadikan kalung dan gelang akan kelihatan indah dan artistik. Pengembangan cinderamata ini baru dalam tahap sederhana dan untuk ke depan akan dikembangkan secara baik, sehingga dapat dijadikan cinderamata untuk wisatawan dan dapat dijual ke daerah lain sebagai bahan kerajinan lokal Desa Tista.

\subsubsection{Berbagai Lukisan}

Di Desa Tista ada salah seorang warganya yang mempunyai bakat melukis dan mengembangkan berbagai lukisan, di mana bakat melukisnya tersebut baru sebatas untuk memenuhi hobinya saja. Padahal lukisan yang dihasilkan mempunyai nilai keindahan. Dengan dikembangkannya Desa Tista sebagai Desa Wisata, maka bakat melukis yang bermula dari hobi ini akan dikembangkan secara profesional, sehingga dapat dijadikan cinderamata lokal untuk wisatawan yang datang ke Desa Tista. Sebelumnya, karena permintaan yang tidak ada, maka potensi lukisan ini tidak begitu kelihatan. Tetapi seiring perkembangannya, cinderamata lokal dari lukisan ini akan dikembangkan secara optimal untuk mendukung pengembangan Desa Tista sebagai Desa Wisata. 


\section{KESIMPULAN DAN SARAN}

\subsection{Kesimpulan}

Dari hasil Kegiatan Udayana Mengabdi Fakultas Pariwisata, Universitas Udayana yang dilakukan di Desa Wisata Tista berkaitan dengan pengkemasan kuliner lokal dan cinderamata lokal, maka dapat disimpulkan sebagai berikut.

1. Potensi wisata Desa Wisata Tista sangat besar untuk dikembangkan, yang meliputi: potensi alam, potensi budaya, dan potensi manusia.

2. Banyak aktivitas wisata yang dapat dikembangkan di Desa Wisata Tista yang dapat dilaksanakan oleh wisatawan bersama-sama masyarakat lokal demi meningkatkan pendapatan masyarakat lokal.

3. Yang diperlukan untuk melestarikan kesan terhadap wisatawan adalah cinderamata lokal yang sesuai dengan karakter daerah termasuk beragamnya kuliner lokal Tista dapat dikemas menjadi cinderamata lokal.

4. Dari pemahaman dan keterampilan yang diperoleh oleh masyarakat Tista, maka perlu dibentuk suatu organisasi dan sistem pengelolaan yang baik untuk mengatur kegiatan pengkemasan kuliner lokal dan pengadaan cinderamata lokal, sehingga masyarakat Desa Tista secara langsung berpartisipasi aktif dan turut memonitor kelestarian dan kebutuhan yang diperlukan pada Desa Wisata Tista.

5. Masyarakat Desa Tista secara langsung pada sesi diskusi meminta agar Tim Udayana Mengabdi Fakultas Pariwisata, Universitas Udayana untuk memberikan sosialisasi tentang topik-topik yang lain yang sesuai dengan perkembangan kepariwisataan terkini.

6. Kendala yang dihadapi masyarakat Desa Tista dalam pengkemasan dan pengembangan kuliner lokal serta cinderamata lokal adalah kurangnya pengetahuan dan pemahaman masyarakat tentang penyediaan dan pengembangan ide-ide kreatif yang diperlukan, sehingga tujuan dan manfaat yang ingin dicapai dari Kegiatan Udayana Mengabdi ini sangat sesuai dan dapat diperoleh.

\subsection{Saran}

Saran yang dapat diberikan dari hasil kegiatan ini adalah:

1. Pemerintah Kabupaten Tabanan, dalam hal ini Dinas Kebudayaan Dan Pariwisata Kabupaten Tabanan hendaknya secara rutin turun ke masyarakat untuk memberikan penyuluhan kepada masyarakat tentang pengkemasan kuliner lokal dan pengembangan cinderamata lokal di Desa Wisata Tista.

2. Pihak terkait senantiasa membantu memasarkan produk kuliner lokal dan cinderamata lokal yang diproduksi oleh masyarakat Tista sendiri, sehingga dalam perkembangannya menguntungkan secara ekonomi kepada semua pihak juga tidak merusak alam lingkungan serta budaya masyarakat Desa Tista.

3. Mulai saat ini mari kita tingkatkan budaya mencintai produksi dalam negeri kita sendiri, dengan memanfaatkan kekayaan yang kita miliki dan dihasilkan oleh anak bangsa kita sendiri.

4. Mari kita merubah orientasi perkembangan kepariwisataan di Bali umumnya dari money oriented menjadi environmental oriented dan community oriented.

5. Masyarakat Desa Tista mau/tidak mau harus mempersiapkan SDM untuk menghadapi perkembangan kepariwisataan berkelanjutan pada Desa Wisata Tista dan menghadapi persaingan global. 


\section{UCAPAN TERIMAKASIH}

Pertama-tama Puja dan Puji Syukur Kehadapan Tuhan Yang Maha Esa sebagai Guru Utama dalam kehidupan di alam semesta ini. Selanjutnya, terima kasih yang sebesar-besarnya kepada Dekan Fakultas Pariwisata beserta Para Wakil Dekan serta Kaprodi Program Studi D-IV Pariwisata beserta jajarannya yang sudah memberikan kesempatan kepada kami untuk dapat berkiprah dalam Kegiatan Pengabdian Masyarakat Udayana Mengabdi serta tidak lupa rasa terima kasih kami yang sebesar-besarnya kepada Ketua LPPM Universitas Udayana beserta jajarannya pula yang selalu memotivasi kami untuk selalu mengikuti berbagai Skim yang disediakan, di mana dalam hal ini kami diberi kesempatan pada Skim Udayana Mengabdi dengan besar pendanaan yang disetujui adalah Rp. 10.000.000,- (sepuluh juta rupiah). Juga terima kasih kami kepada teman-teman Dosen yang selalu saling mendukung dan saling memotivasi untuk kelancaran pelaksaan berbagai kegiatan yang dilaksanakan masing-masing. Semoga program-progam yang positif tersebut selalu dapat memotivasi Dosen untuk dapat berkarya lebih baik dan lebih baik lagi.

\section{DAFTAR PUSTAKA}

Abidin Hamid. 1981. Mycotoxin in Food and Agricultural Products -Aflatoxins. MARDI.

Bullermann, L.B. 1979. Significance of Mycotoxins to Food Safety and Human Health. J. Food Protection

Fagence, Michael, 1997. Approches to Planning for Rural and Village Tourism Realizing The Potential of Rural Areas an Village. Proceedings on the training and workshop on Planning Sustainable Tourism, ed. Minnery, John, Gunawan Myra, P. Penerbit: ITB, Bandung.

Furia, T.E. 1968. Handbook of Food Additives. The Chemical Rubber Co, Cleveland.

Hermantoro, Henky, dkk. 2010. Pariwisata Mengikis Kemiskinan. Jakarta: Pusat Penelitian Dan Pengembangan Kepariwisataan.

Kusumahadi, M. 2007. Practical Challenge to the Community Empowerment Program. Yogyakarta: Experience of Satunama Foundation of Yogyakarta.

Korten dan Syahrir (ed.) 1988. Pembangunan Berdimensi Kerakyatan. Jakarta: Yayasan Obor Indonesia.

Mathieson, A. dan Wall, G, 1982. Tourism Economic, Physical and Social Impacts. Longman Group Limited. New York.

Monografi Desa Tista, Kecamatan Kerambitan, Kabupaten Tabanan. 2016

Page, S.J. dan D. Getz (eds.). 1997. The Business of Rural Tourism. London: International Thomson Business Press.

Sutrisno, 1999. Pemberdayaan Masyarakat. www.pemberdayaan.com. Accessed on Pebruari 2013. 